\title{
Research on the Present Situation of ESP Teaching Reform in Local Engineering University in China
}

\author{
Junyan Cai, Kun Yang, Rui Liu \\ School of Foreign languages, Hebei University of Technology, Tianjin, 300230, China
}

Keywords: Engineering Colleges, ESP Teaching Reform, English Teaching

\begin{abstract}
With the increasing of internationalization tendency in TESOL, it is very important to improve the students' application and presentation ability for English. However, in engineering university, to carry out the science and engineering course is the favourite subject, while English is partial class, and the students' interest in learning English is at a low, so teaching reform faces obstacles. For this reason, this paper mainly provides a comprehensive analysis of English for Special Purpose (ESP) oriented college English Teaching, and then provides the opportunity for the students of science and engineering colleges and universities to create a favorable environment, and puts forward some suggestions for teaching reform.
\end{abstract}

\section{Introduction}

With the further development of college English teaching in China, the teaching mode, teaching method and course installation of college English are all going through reform. In the teaching reform, the demand for the colleges and universities is to improve and adjust the teaching mode and teaching content. The Ministry of education published College English Teaching Reform Compendium in 2008, that is, Teaching Requirements of College English Curriculum, and pointed out the teaching objectives, requirements and others for the current college students English course, that is, to continue to develop students' comprehensive ability to use English, through English learning to get more professional skills, learning methods, etc.. However, for a long time, the College English Teaching in our country pays more attention to the basic language knowledge, but little to English learning. The students' ability to communicate in English is weakened, English language talent remains scarce in society.

\section{The difference and relation between general English and professional English}

As early as 1996, some educators had predicted that by twenty-first Century, English teaching reform will be an inevitable way to promote the development of professional English." In the teaching content and subject setting, the advantage of ESP is still obvious. ESP teaching research is the teaching theory which sprang up in 1980s, and its formulation of teaching objectives can be made based on the students learning needs, and the teaching content is closely linked to practice teaching. The students can get more English learning skills through this ESP course. The social and individual learning needs of ESP can be shown to be service, professional and instrumental characteristics. In order to maximize the ability of English application, China has carried out a lot of ESP teaching theory and practice, and most of the colleges and universities have been guided by this teaching method to the reform of English teaching, so that the combination of ESP theory teaching and practical application, and then cultivate the compound talents of social real need ${ }^{[1]}$.

\section{The differences in usage between general English and ESP}

EGP is short for English for General Purpose, which represents a kind of basic English, and the teaching goal of EGP is to make the students have the skills of listening, speaking, reading, writing and translating, and build capacity of English communication and language expression of students. General English mainly refers to the content of English Teaching in primary and middle schools, and 
after entering the university, most of the English teaching methods have been changed, mainly in the EGP as the main theoretical support for English teaching. The students' English level in middle school is influenced by the reform of the teaching system, which is in the process of continuous improvement, the vocabulary number of students in the high school will reach 4000 words as same as the level of CET-4 words, after the students enter the University, they just repeated review words learned before, so their interest is greatly reduced, and the learning efficiency is not high ${ }^{[2]}$. Also, the university English teaching pays great attention to developing the student's basic language ability, not to the content and the practical function.

In the teaching process of English for General Purpose(ESP), it will be based on the students' basic language level, and make the basic knowledge as a starting point for English learning, and then make the students to learn English as a tool for information acquisition, rather than a learning task. ESP can be regarded as the direction and attribution of the reform of college English teaching, and allow the English knowledge to be closely aligned with professional skills, in view of the special purpose of English in vocabulary, grammar, and the differences in general English, for this purpose, the students only with special English learning can lay a solid foundation for future study and work.

\section{The relation between general English and professional English}

General English and ESP Special English are the use of English teaching stage, for this purpose, the relationship between the two is the interaction and mutual support. General English pays more attention to the students' language foundation, while ESP pays more attention to the cultivation of the ability of language communication. It can be said that the bridge between special English and EGP needs the construction of ESP. The curriculum bases of ESP has become an extension of English teaching, and it is the transition from professional English, which plays a continuous and throughout role ${ }^{[3]}$. Based on the expansion of basic English, we get the ESP teaching, and the students can improve the analysis ability of the English article by mastering the professional vocabulary, which lays a solid foundation of English learning.

\section{The conditions for the development of College English ESP teaching in science and engineering colleges}

In view of its strong professional ability, science and engineering colleges and universities can take the ESP theory as a mainstream teaching reform, in the curriculum setting, usually use the ESP English teaching theory, and then enable students to contact with the ESP curriculum, learning English with a strong practice performance can improve students' learning efficiency. In addition, ESP and basic English develop the teaching based on the same teaching objectives, and the difference lies in the different levels, in the college English teaching, the combination of ESP and basic English teaching is a feasible method. Under this background, the science and engineering colleges and universities have the conditions for:

\section{The implementation of college English teaching reform}

As the national education department gradually pays attention to the college English teaching, College English teaching reform is further deepened and promoted, for this reason, the education department has introduced the guidance document to support the reform, thinking that the final ascription of English learning is application, practicability is the ultimate goal of English teaching reforming ${ }^{[4]}$. In addition, the demand for English talent has also promoted the development of English teaching reform, and provides the opportunity for the optimization and adjustment of teaching reform. Therefore, it is necessary to cultivate students' ability of language use in the professional field according to the current professional learning situation of the students. 


\section{Improvement of English Teaching in primary and middle schools}

From the above discussion, we can understand that the English vocabulary in primary and middle schools has reached the level of CET-4, the teaching level is still improving. After entering colleges, students' English foundation will be greatly enhanced. In order to spare more time to study professional courses for the students, the teaching of English Teaching in Colleges and universities has been compressed, while create conditions for ESP entering college English teaching.

\section{Our country supports the ESP curriculum reform}

ESP teaching theory has achieved remarkable results, and the ESP curriculum research is also increasing, at the same time, the teaching reform has more policy support, and under these support, the teaching achievement is very significant. Especially, as the industry reference books have emerged, different disciplines begin to be compatible and thus, and provide support for the depth of the ESP teaching, and the integration of ESP and the relevant professional is gradually enhanced.

\section{Three, Strategies for the ESP teaching reform of College English in Colleges of science and Engineering}

\section{According to the students' learning level to take the method of Graded Teaching}

At present, most of the science and engineering colleges and universities do not value the development of English curriculum, after the entrance, the majority of English tests of students with uneven English level are not qualified, which seriously hindered the university English learning effect, but some students with a level at CET-4 or CET-6 through the efforts are interested in English learning, but it is only a small part, and to strengthen the consolidation and review of English knowledge constantly is very important. Therefore, in view of the above situation, the use of graded teaching method, and constantly strengthen the foundation of English foundation weak students, after the basic English learning of these English foundation weak students reaches the acceptance level, you can enter the next stage to continue to learn, that is, ESP learning stage. The students with good English can directly learn the ESP course after the entrance, so that the basis of the accumulation in the past can reduce the repetition in the learning process, can be organized, have the order of the completion of English knowledge learning, and learn the language knowledge in order, and the efficiency and quality of the study can be enhanced.

\section{Setting up the teaching content of ESP course according to the specialty structure}

Generally, ESP can be divided into the following two forms, that is, dichotomy and trichotomy. The dichotomy is that the ESP is divided into professional English and academic English, the two branches of the English category is an important component of ESP. While the which is the ESP course can be divided into Scientific and Technological English (EST), Social Science English (ESS) and Business Trade English (EBE) the three types according to the practical application, and it also can be divided into professional English and academic English the two kinds. The practice proves that these types of English have a guiding role on the ESP curriculum. Science and engineering colleges and universities have a strong discipline advantages, and they can put these subjects into the ESP teaching, such as computer, network media and so on, and so the teaching can be carried out in a multi-level, all-round development.

And for some science and engineering colleges with strong professional characteristics, the link and and the difference of special vocabulary and general vocabulary between the ESP has become an important content of ESP, but also the source of the word formation. In addition, the syntax and sentence structure of ESP.in is also the content that teaching need to pay attention to ${ }^{[5]}$. The structural analysis of ESP is a difficult problem in the teaching process. And it needs to be combined with the specific context and requirements of practice, so that students can experience the learning characteristics of different types of English. 


\section{According to the teaching needs to write a reasonable ESP teaching material}

Teaching material is the carrier of knowledge, a platform for teaching activities, and an important source of teaching content. At present, the systematic and planned ESP teaching materials are still very short in China, the situation of the materials shortage will be a direct impact on the smooth development of ESP teaching, and bad for the quality and effect of teaching, in this case, the ESP teaching effect is not very ideal. Therefore, English teaching materials should reflect the true, communication, and the principle of "people-oriented", and put it ti be an important teaching elements. Many subject areas are involved in the preparation of ESP teaching materials, and many of them are highly professional discipline, for this purpose, the task and intensity of the preparation are difficult. On the other hand, the lack of supervision and evaluation in the quality of ESP teaching materials, leads to that the majority of domestic colleges and universities use the ESP teaching materials which mostly are introduced from foreign, the preparation of personnel adapted it based on the introduction of teaching materials, the lack of professional knowledge of the materials involved in the preparation, the quality of teaching materials is not up to standard. Therefore, English teachers can complete the task of compiling the teaching material in the way of cooperation with the specialized subject teachers. This kind of interdisciplinary cooperation will make the teaching material more comprehensive and more efficient. ESP is characteristics of the students' needs as the starting point, combined with the characteristics of the subject, to compile the teaching material with the needs of personnel training, but also to meet the needs of students' personalized needs.

\section{Strengthen the training of qualified ESP teachers}

The teacher's power is an indispensable carrier in the process of university personnel training, and it is also the key factor to determine the level of College English. The teacher is the most important part of English teachers in our college. And domestic colleges and universities will introduce some foreign English talent with professional English learning background, but these English teachers can not play its value, the usage of teaching methods is old-fashioned, and students' interest in learning is not high. For this reason, the science and engineering colleges and universities can use their own powerful professional power to solve the problem of shortage of teachers. The science and engineering colleges and universities should provide the training of ESP teaching course, the multi organization teachers participate in the academic discussion and exchange, and more for the teacher to create the opportunity to go abroad for further study, and enhance the confidence of teachers, so that the English teachers not only have the ability to study and research, and to join the practice of teaching practice to protect the interests. In addition, the teachers themselves should be kept in a wide range of mind, to read more English books, periodicals, etc., the know the most advanced knowledge and teaching requirements. In a word, in the reform of English Teaching in science and engineering colleges, the teachers' power is the important part of the reform.

\section{Conclusions}

With our open degree deepened, international exchanges and cooperation are becoming more frequent. Although the professional discipline construction in science and engineering colleges is very strong, but English teaching can't meet the demand for high quality of English talents, and the disadvantages of traditional English teaching methods are gradually exposed. Therefore, ESP teaching has become an inevitable trend of the reform in English Teaching in science and engineering colleges. In order to improve the comprehensive application ability of English, science and engineering colleges should not only develop characteristic teaching method, but also focus on the training of comprehensive personnel, to ensure that the College English teaching reform achieves remarkable results. 


\section{Acknowledgments}

This paper is the research project of educational teaching reform for Hebei University of Technology in 2015, Item number:201502025; The research project of humanities and social sciences in colleges and universities in Hebei province in 2015, Item number:SZ151252

\section{References}

[1] Wei Yanmei, Chen Shifang. The challenges and outlets in the teaching reform that ESP is introduced to college English in independent college. Campus English(the latter part of a month),2014(12):41-41.

[2] Zhang Jing, Jiang Baode. Taking Service English in Cabin as an example to discuss the teaching reform of ESP.The Divine Land ,2014(7):61-62.

[3] Yang Miaojie. Research on the ESP teaching based on the combination of content and skill. Journal of Hubei Correspondence University,2014(9):170-171.

[4] Yu Jie. A discussion on the introduction of the ESP course in the Art College English -- a case of the questionnaire of broadcasting. Science Time,2012 (3); 250-251.

[5] Qin Xiubai. The nature, scope and teaching principles of ESP -- The feasibility of conducting various types of English teaching in colleges and universities in China. Journal of South China University of Technology(Social Science Edition), 2010, 5(4) :79-83. 